\title{
Object and Objectivity in Divination
}

\section{Sónia Silva}

To cite this article: Sónia Silva (2016) Object and Objectivity in Divination, Material Religion, 12:4, 507-509, DOI: 10.1080/17432200.2016.1227638

To link to this article: http://dx.doi.org/10.1080/17432200.2016.1227638

$$
\text { 曲 Published online: } 21 \text { Oct } 2016 .
$$

Submit your article to this journal ๘

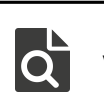

View related articles $\longleftarrow$

View Crossmark data ¿ 


\section{object and objectivity in divination}

\author{
sónia silva
}

Crystal gazing, palm reading, astrology, the oracle of Delphi, dream interpretation, casting lots, piromancy, Ouija boards, birds in flight, poison oracle, bibliomancy. The sheer variety of divination methods, past and present, is staggering. No less intriguing is the recurrence of the same patterns in different methods, a topic of great interest to scholars of divination since antiquity. Referring to ancient Greece, Plato proposed a sharp distinction between "inspired prophecy" (mantike entheos) and the rational observation of birds in movement and other signs (mantike technike) by diviners who were "in their right mind." We continue to honor this distinction between mediumistic divination and the inductive study of various patterns.

At the same time, however, we know that methods of divination do not always fit into either of these two categories. The inductive methods may display mediumistic features such as spirit possession. In the Upper Zambezi region where the countries of Zambia, Angola and the Democratic Republic of the Congo share borders, basket diviners closely examine and rationally interpret the configurations of symbolic pieces contained in their baskets; yet they are possessed by an ancestral spirit. Conversely, however inspired and ecstatic, mediumistic sessions may include inductive interpretation. At one point in their séances, the Navajo mediums in the American Southwest interpret mandala-like sand paintings drawn on the floor. Likewise in ancient Greece. In addition to conveying Apollo's words in a prophetic, trance-like state, the Delphic Pythia also drew lots. The closer we look, the more we
Sónia Silva is Associate Professor at Skidmore College. She is the author of Along an African Border: Angolan Refugees and their Divination Baskets (2011). ssilva@skidmore.edu
And this leads us to another remarkable similarity. The rigid opposition between natural inspiration and the artificial observation of omens and signs, to use once again the language of Plato, hides from view one important fact: in divination, truthful knowledge is often revealed through material, visible forms, from artifacts and lightning to oneiric images. I want to explore this link between divinatory knowledge and material religion, objectivity and objects.

Regardless of method, divination provides an answer to practical yet difficult questions that lie beyond human grasp. Oracular messages constitute a form of objective knowledge, untainted by personal biases and opinions. This being the case, we should reframe the relation between knowledge and materiality in the world of divination as a relation between objectivity and objects.

To begin our exploration of objects and objectivity, let us return to the topic of basket divination, a technique in which the diviner, who is always a man, tosses thirty or so small pieces in a woven basket (see Figure 3). Sitting across from the diviner, the consulters listen to the diviner's words, observe the divinatory pieces as they land inside the basket, and agree or disagree with the diviner's conclusions when asked. Should they stray from the ritual script, the diviner will correct them.

Based on ethnographic fieldwork conducted in northwest Zambia, I should mention that the consulters take several important steps to ensure objectivity. Because they are after the true knowledge revealed by Kayongo, an ancestral spirit associated with basket divination, they will not discuss their case with the diviner prior to their séance, and much less request his personal opinion and advice. Nor will the consulters approach a diviner who lives nearby. Physical proximity increases the likelihood that the diviner will either be familiar with the details of their case or, to their dismay, unscrupulously attempt to gather information prior to divining. Such misconduct would jeopardize the entire session. To be successful, a séance should yield spiritual, truthful knowledge, untainted by human bias, personal opinion and misconduct.

This said, the heaviest responsibility to ensure the smooth delivery of true knowledge falls on the diviners. In addition to escorting their clients through the divination process, diviners have responsibilities of their own. Diviners must strictly follow a number of taboos. Should they eat cassava leaves cooked with plant ashes, a dish with a slimy consistency, they will miss the truth while divining. Diviners must also perform several rites during their séances, including the ritual 


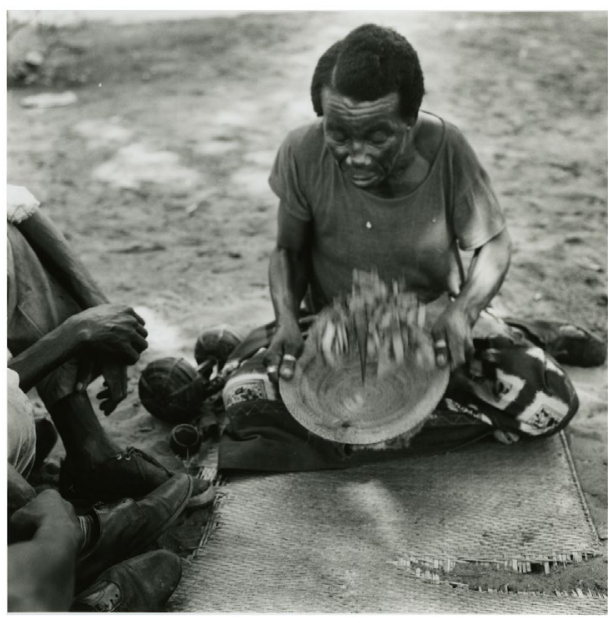

FIG 3

A basket diviner tossing his divinatory pieces. Dundo, Angola, 1971. Photo by Benjamin Pereira. Courtesy of Museu Nacional de Etnologia, Portugal.

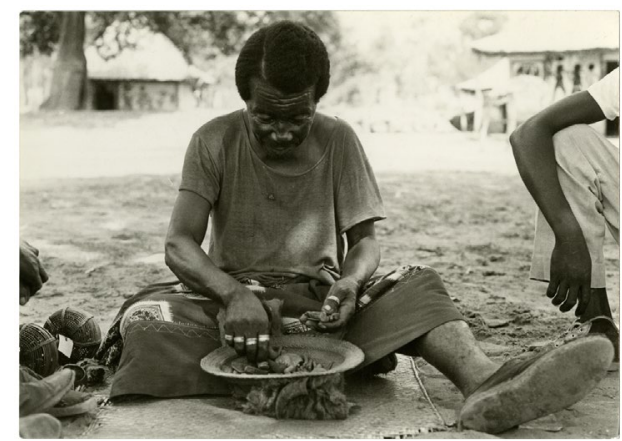

\section{FIG 4}

A basket diviner interpreting a configuration of pieces for his clients. Dundo, Angola, 1971. Photo by Benjamin Pereira. Courtesy of Museu Nacional de Etnologia, Portugal.

marking of their eyelids with red ochre dust. This simple but indispensable rite ensures that they see clearly and muster the courage to reveal the truth without fear. By taking all the prescribed steps, ordinary men become potent diviners.

Interestingly, in order to be powerful and respected, basket diviners must be reduced to the condition of vessels and vehicles for Kayongo. A successful divining session is one in which Kayongo reveals the truth in the material form of patterned configurations, which the diviner, possessed by Kayongo, promptly interprets and translates into the medium of words. Addressing their clients at key moments, the diviners point to particular pieces inside the basket. They might say, "See, here is the Path (a grooved wooden piece named Path, or Jila, in the Luvale language) that you took to the funeral; and here is the Dead Person (or Mufu, a roughly cylindrical shape tied to a thin pole), who was buried that night" (see Figure 4). The revelation of objective, truthful knowledge coincides with the de-subjectivation of the diviner and the materialization of that knowledge. In basket divination truthful knowledge is knowledge materialized in the form of jipelo, as the divinatory pieces are known in Luvale.

Objectivity and objects being closely related, it should not surprise us that truthful, objective knowledge is known as chinyingi, a term derived from the verb kunyingika, meaning to know. Similarly, in addition to being known as jipelo, the divinatory pieces are often termed tutachikijilo, from kutachikiza, another verb meaning to know. The relation between objective knowledge and the divinatory objects is explicitly recognized through knowledge concepts that share the same roots.

One last word on the importance of seeing and observing in basket divination: not only do the consulters feel reassured by seeing divinatory statements take the form of visible, material objects, but seeing is also defining of the work and the gift of divining. Regardless of the method used, all diviners are known as vakakutaha, literally "those who divine," from the verb kutaha, to divine or see. Similar to the English "diviner," the Luvale "mukakutaha" means "seer." Diviners are seers. And yet only basket diviners are described as eagle-owls.

The importance of objectivity in basket divination and other divination methods invites a comparison with positivist social science. Divination and positivist science share a similar emphasis on objectivity, detachment, observation, and true statements. However, rather than defining divination through a comparison with science, it is more fruitful to approach it on its terms. What do we learn from basket divination? What do we learn from divination in general? In this spirit, I propose four points as food for thought.

My first point is a gentle reminder that the human search for truthful, objective knowledge has been a constant in human life for thousands of years. Objectivity is by no means an invention of the Enlightenment or positivism in modern northern Europe. Acknowledging the contributions of the eighteenth-century philosophers and nineteenth-century positivists should not come at the cost of ignoring the countless people (some of them scientists with PhDs), who have searched for truthful, objective knowledge 
through divination methods. As early as 2700 $\mathrm{BCE}$, people in ancient China were reading patterns on oracular bones. This is among the earliest known forms of divination.

Moving from science to religion, the arts of divination show that the idea of objectivity and religion are not at odds with one another. This is my second point. Again, the war waged on religion and the supernatural by Enlightenment and positivist thinkers might lead us to think otherwise, but the search for objective, unbiased knowledge is not the purview of secularism. Numerous individuals would contend that objectivity is at the heart of several religious practices, including the diviners and their clients.

Onward to the third point: true knowledge is not always scholarly knowledge produced in an ivory tower. Not only does divination show that true knowledge has a special place in everyday life, but the materialization of that knowledge facilitates coping and decision-making. Consider the case of basket divination. By seeing their lives reshuffled in a basket, and revisiting past events in the material form of divinatory pieces, many consulters make sense of painful experiences, gain resolve, and take concrete steps toward some form of resolution.

In my fourth and last point, I return to the idea of objects and objectivity. Objectivity is coextensive with the material world. As material religion and material knowledge, divination practices challenge us to consider the relation between objectivity and object-hood, two words with the same root. We continue to struggle with the pervasive tendency to value the subject over the object, the independent subject over the dependent object. By disclosing the degree to which the production of knowledge-particularly objective knowledge-extends to the realm of objects, the institution of divination challenges this old dichotomy. We depend on material objects to generate true knowledge.

We also depend on material objects to mitigate suffering, clear the mind, and jump to action. In times of need we often turn to our non-human, material associations. More versatile in shape, size, substance, and ability, and notoriously free of human bias, such things as divination baskets, pebbles, and flying birds make the perfect oracles. 